\title{
Assessment for Learning: Changes in the Role of Assessment in Learning
}

\author{
Tatang Mulyana ${ }^{1}$, Surti Kurniasih ${ }^{2}$, Didit Ardianto ${ }^{3}$
}

1,2,3 Universitas Pakuan, West Java, Indonesia

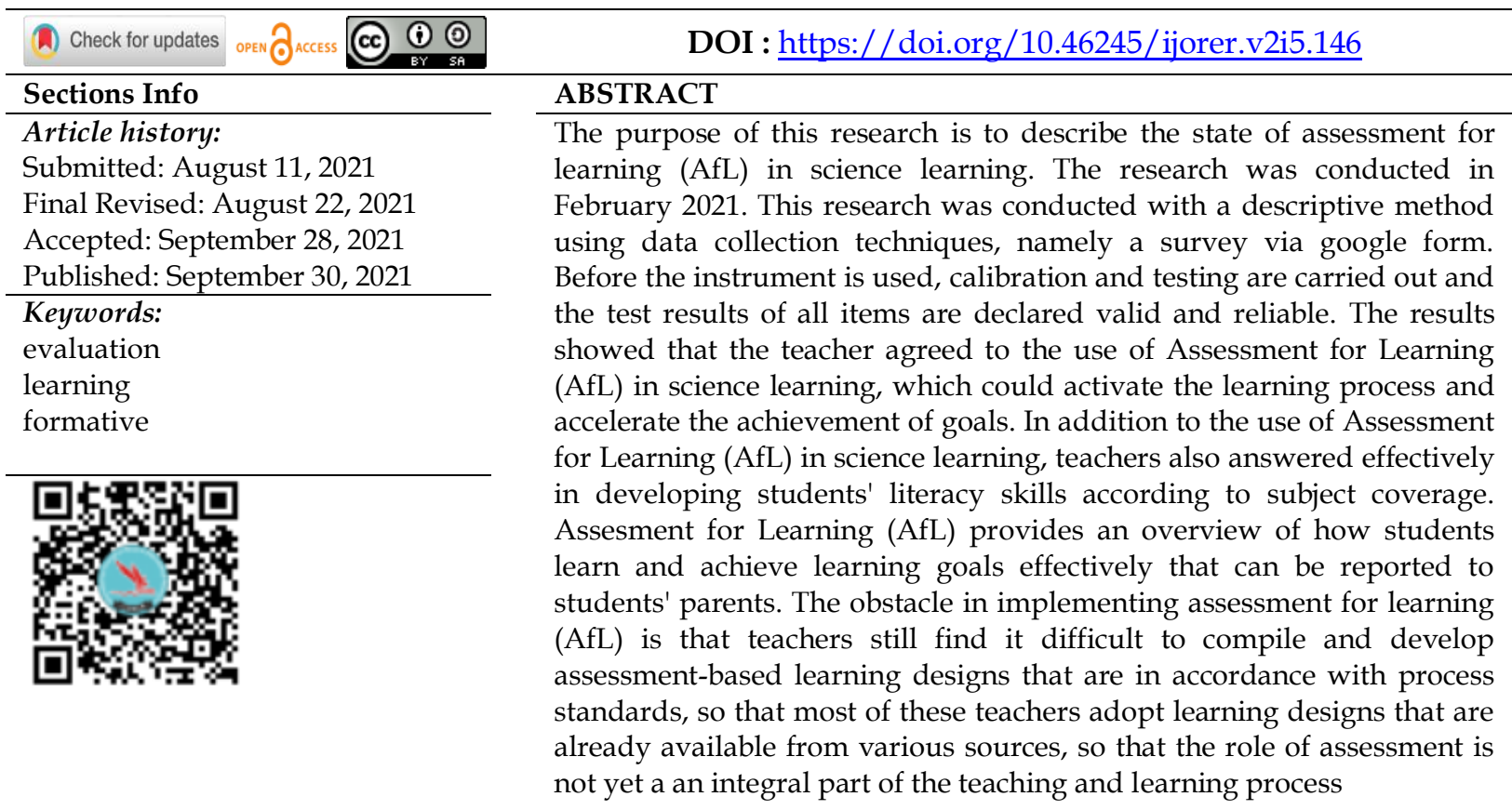

\section{INTRODUCTION}

Assessment describes an integral part of learning. Assessment describes the necessary factors of the process of learning activities. Assessment includes gathering information through various assessment methods and making decisions based on the results of these assessments. Science education for the 21st century Over the past decade, studentcentered approaches to teaching, learning and assessment have become an important part of the curriculum reforms that have been gradually implemented in science and technology education (Spector et al., 2016).

The current reform emphasizes the relationship between teaching, learning and assessment processes in creating meaningful learning. The main goal of the reform is to enable students to interpret information, make connections between facts, think about their learning process and organize their learning (Lasry et al., 2014).

Improving the quality of teaching in the classroom that raises scientific literacy skills is needed to improve students' scientific literacy skills (Sulhadi, 2017). Learning is conceptualized as a process of character change as a result of individual relationships with their environment. Acording to While learning is an activity that takes place through levels, arrangements, implementation, and assessment (Hanafy, 2014).

In classroom learning, teachers have two main goals, to lead students to reach the minimum competency limit and develop students' literacy skills according to the scope of the subject. For it reason, a teacher needs to design indicators represent the condition 
of students. Both indicators that students pass the minimum limit and need enrichment as well as indicators the minimum and remedial limits have not been achieved.

The most frequently used and developed indicator in the world of assessment is the assessment of learning (AoL) or summative. In fact, apart from this assessment, there is another type of assessment, namely assessment for learning (AfL) which is no less important. It is very certain, if the assessment only covers AoL then the first main goal can be achieved, while the second goal will be difficult to achieve Teachers who tend to use a teacher-based approach, use traditional assessment tools, while teachers who allow students to work together rather than compete with each other tend to use formative assessment tools (Alt, 2018). Teacher practice and personal qualities that are an integral part of effective teaching and optimizing student learning. They include; 1) Professional Knowledge, 2) Instructional Planning, 3) Differentiation Instructions, 4) Formative Assessment, 5) Treatment, and 6) Practical Wisdom (Nwani, 2021).

A number of researchers specifically examine AfL, which covers various issues such as the application of AfL in learning to write (Lee and Coniam, 2013), prerequisites for implementing AfL in learning (Heitink et al., 2016), teachers' views on AfL and databased decision making (Kippers et al., 2018), and a meta-analysis of Afl research in East Asian countries (Leong et al., 2018). Several studies reveal effective results related to the function of assessment as a natural companion in learning mathematics (Balan, 2010; Chueachot et al., 2013). This is in line with the results of Purnomo's research (2015), which found that there was an increase in the ability of elementary school students to solve math problems through an assessment design that had been developed.

However, there are still many teachers who do not understand the use of AfL. Therefore, it is not surprising that only a few teachers have implemented AfL in their learning. (Kippers et al., 2018), report that only about 10-25 percent of teachers integrate AfL in their learning in the classroom. In addition to the limited understanding of AfL, teachers also face obstacles in implementing AfL, such as pressure from parents who are still oriented towards national exam scores (Leong et al., 2018).

Based on the research report that not many teachers understand and implement AfL, through this article we would like to describe teachers' views on AfL in learning in schools. More specifically, in this article, we will explore teacher responses regarding the use of assessment for learning, teacher responses regarding the effectiveness of assessment for learning and details on the use of assessment for learning in science.

\section{RESEARCH METHOD \\ General Background}

This research was carried out with a descriptive method using a data collection technique, namely a survey. The study was conducted in February 2021. The purpose of this study was to describe the state of assessment for learning (AfL) in science learning. This research was carried out with a descriptive method using data collection techniques, namely surveys via google form.

\section{Sample}

The subjects in the study were science teachers (Physics, Chemistry and Biology) in the Subject Teacher Consultation (MGMP) at the high school level in Sukabumi Regency for the 2020/2021 academic year, totaling 20 teachers.

\section{Instrument and Procedures}


The instrument made is in the form of a questionnaire or questionnaire containing questions about various teacher opinions regarding Assessment for learning (AfL) which are distributed through social media, in the form of Google form. Questionnaires or questionnaires are a number of written questions that are used to obtain information from respondents in terms of reports about themselves, or things they know (Ansarin and Khatibi, 2018; Azman et al., 2018; Tagg and Wang, 2016; Wijekoon et al., 2017; Yusrizal et al., 2017). The questionnaire used is a closed and open questionnaire. The reason for choosing the questionnaire in this study from a technical point of view of the implementation of the questionnaire is the method that is most effective, efficient, and saves time, energy, and costs in the research process.

In this study the instrument consisted of 3 parts, namely 1) teacher responses related to the use of assessment for learning, 2) teacher responses related to the effectiveness of assessment for learning, and 3) details on the use of assessment for learning in science learning. Before the instrument used in the actual research, calibration and testing are carried out to determine the level of validity and reliability of the instrument. The results of the research instrument trials that have been carried out and analyzed with $r$ table $(0.05)=0.444$, it is stated that all items are valid and after being continued with reliability testing at a critical level of 0.60 all items are also declared reliable

The first instrument related to the teacher's response in the use of Assessment for learning has answer choices of strongly agree, agree, undecided, disagree, and strongly disagree. All items in the instrument are positive statements. The second instrument is an instrument in the form of teacher responses related to the effectiveness of the use of Assessment for learning. The answer options provided are ranging from very effective, effective, moderately effective, less effective, and ineffective. Meanwhile, the third instrument is a question with a variety of answers related to details using Assessment for learning. The stages of the process to be carried out in this study are depicted in the flow chart in Figure 1 as follows: 


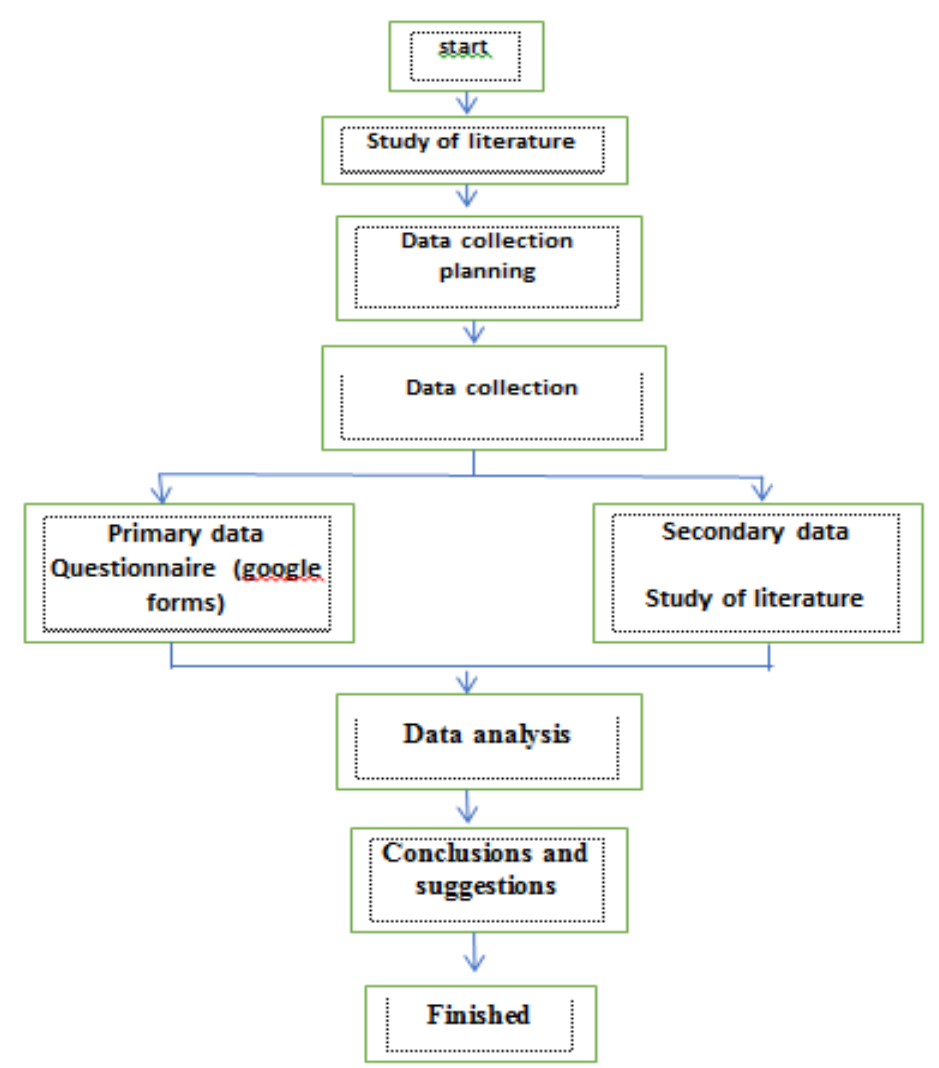

\section{Data Analysis}

Figure 1. Flowchart of research procedures.

Analysis of the data used in this study is to describe the various research results in the form of percentages. This is to see the percentage of the use of this Assessment for Learning in learning science and the environment. The results of data analysis related to learning media and teaching materials used in the Assessment for Learning are presented in the form of tables and graphs. The goal is to make it easier to see the largest and smallest percentages of the teacher's answers.

\section{RESULTS AND DISCUSSION}

Teacher's response regarding the use of assessment for learning

Teacher responses to five questions related to the use of Assessment for Learning (AfL) were investigated and analyzed using descriptive statistical analysis to show the percentage of teacher responses. The results are shown in Figure 2 below. 


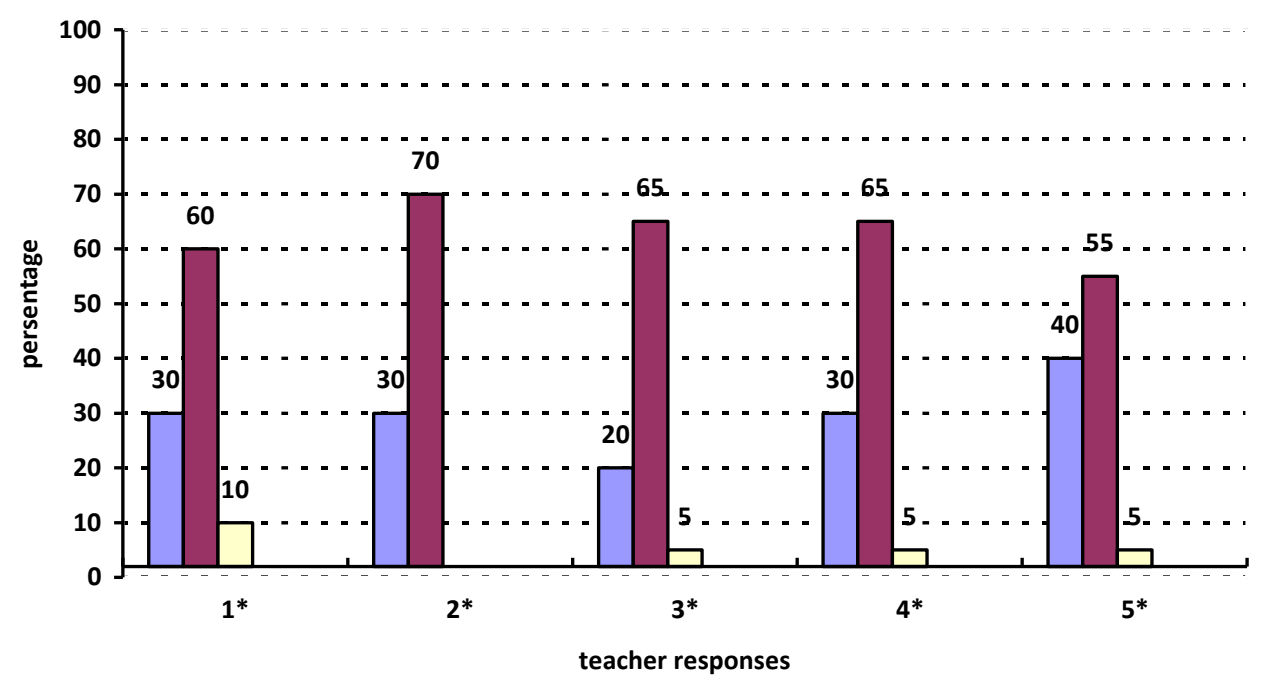

$\square$ Strongly agree $\square$ Agree $\square$ Doubtful $\square$ Do not agree $\square$ Strongly disagree

Figure 2. Percentage of teacher responses related to the use of Assessment for Learning (AfL).

Description:

$1^{*}$ ) In your opinion, the use of assessments carried out during the learning process helps teachers to find out whether students understand or do not understand the material.

$2^{*}$ ) In your opinion, using the assessment carried out during the learning process, students are actively involved in the assessment activity.

$3^{*}$ ) In your opinion, using the assessment carried out during the learning process, students are given the experience to learn to be assessors for themselves and their friends.

$4^{*}$ ) In your opinion, the use of assessments carried out during the learning process activates the learning process and accelerates the achievement of goals.

$5^{*}$ ) In your opinion, using the assessment carried out during the learning process at the beginning of learning, the teacher succeeded in diagnosing student needs and providing targeted feedback.

Figure 2 above shows the percentage of teacher responses related to the use of Assessment for Learning (AfL) in learning. Of the five answers given by 20 teachers, almost all teachers agreed $(\geq 55 \%)$ regarding the use of Assessment for Learning (AfL) in learning and only 5\% said they did not agree with the use of assessments carried out during the learning process, students were given experience to learn to be a judge for himself and his friends.

This shows that overall from the 5 answers given by 20 teachers, in general the teachers agree with the use of Assessment for Learning (AfL) in the implementation of science learning. This is in line with the results of the research by (Mumpuni and Ramli, 2018), which showed that students had agreed and understood the function of AfL, types of assessment and feedback, and the subject of feedback. Likewise, the results of Kurniawan's research (2016), which shows that the application of assessment for learning through peer assessment can improve students' mathematical problem solving abilities better than direct learning. In line with the results of Hignasari and Supriadi, (2020) research which shows an increase in learning outcomes in e-learning learning with the self-assessment method which provides opportunities for students to increase 
their confidence in their mathematical abilities. Because of its benefits, it is highly recommended that this is a golden opportunity to effectively apply assessment for learning (AfL) in L2 writing classes in an EFL academic context with better understanding (Kulprasit, 2021).

Teacher responses regarding the effectiveness of Assessment for Learning (AfL)

The teacher's responses to two questions related to the effectiveness of the Assessment for Learning (AfL) results are shown in Figure 2 below :

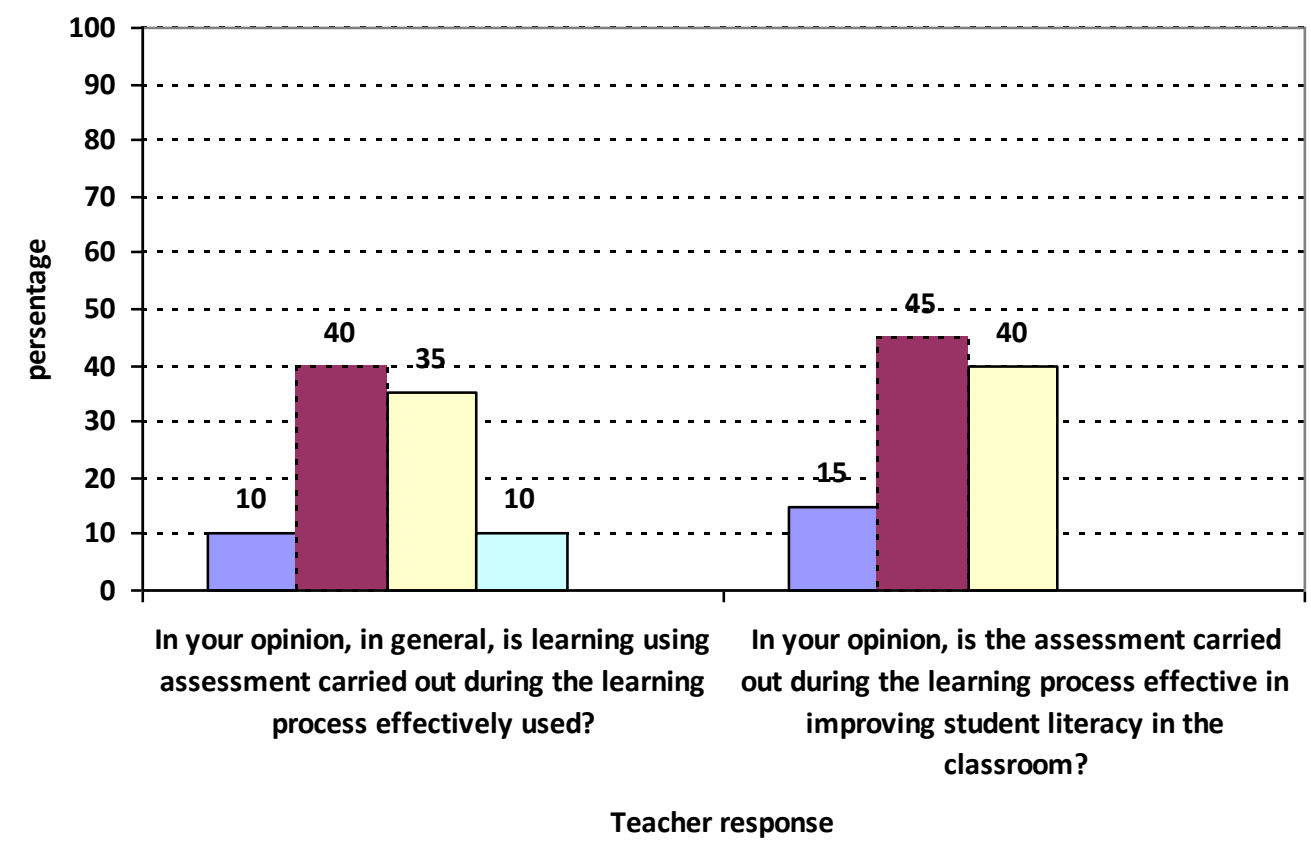

$\square$ verry effective $\square$ effective $\square$ effective enough $\square$ less effective $\square$ ineffective

Figure 3. Percentage of teacher responses related to the effectiveness of the Assessmentfor Learning (AfL).

Based on Figure 2 above, it shows the results of the teacher's response regarding the effectiveness of the Assessment for Learning (AfL) in learning. As many as $45 \%$ of teachers answered learning by using assessments carried out during the effective learning process. This is in line with several research results, which show that the effectiveness of learning in the application of AfL can be influenced by assessment preparation, student involvement and follow-up assessment. The results of the analysis show that the use of AfL can improve student learning outcomes (Triwiyono, 2017; Winorno et al., 2019; Yusron and Sudiyatno, 2021).

According to Eriyanto et al., (2021) student learning outcomes are influenced by learning motivation, a strong learning motivation in learning activities will create a conducive and interactive atmosphere. For this reason, the use of Assessment for Learning (AfL) in learning activities in addition to affecting student learning outcomes, but the most important thing is that during the learning process students are actively involved in these learning activities, so that learning activities become a fun activity not a burden for students.

Meanwhile, only $5 \%$ of teachers answered that the assessment carried out during the learning process was not effective in improving student literacy in the classroom. 
Meanwhile, teachers who answered effectively increased student literacy in class by $40 \%$. This shows that most of the teachers stated that the Assessment for Learning (AfL) in learning is effectively used in learning.

The Use of Assessment for Learning in Science Learning.

The teacher's response to the use of Assessment for Learning (AfL) in science learning, the results are shown in Figures 3 and 4 below :

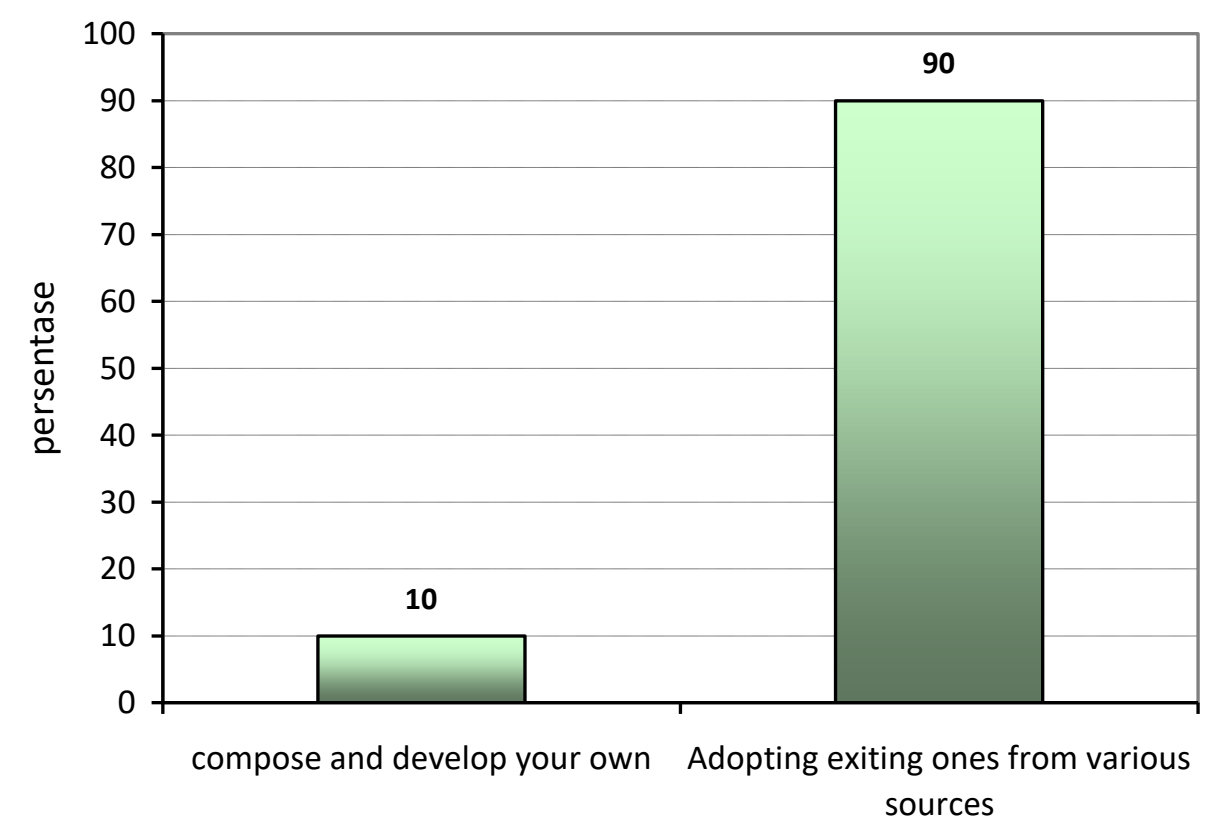

$\square$ teacher's response

Figure 3. Teacher responses to the use of Assessment-based learning designs.

Figure 3 above shows the percentage results of the preparation and development of the use of assessment-based learning designs in accordance with process standards. Of the 20 teachers who answered, $90 \%$ of teachers still adopt existing ones from various sources in the use of Assessment for Learning (AfL) in learning and only 10\% have compiled and developed their own. This shows that teachers still have difficulty in compiling and developing an Assessment for Learning (AfL) that is in accordance with the standard process in science learning.

The following is the percentage of difficulties in the preparation and development of assessment-based learning designs that are in accordance with the standard process of answering the results of 20 teachers, shown in Figure 4. 


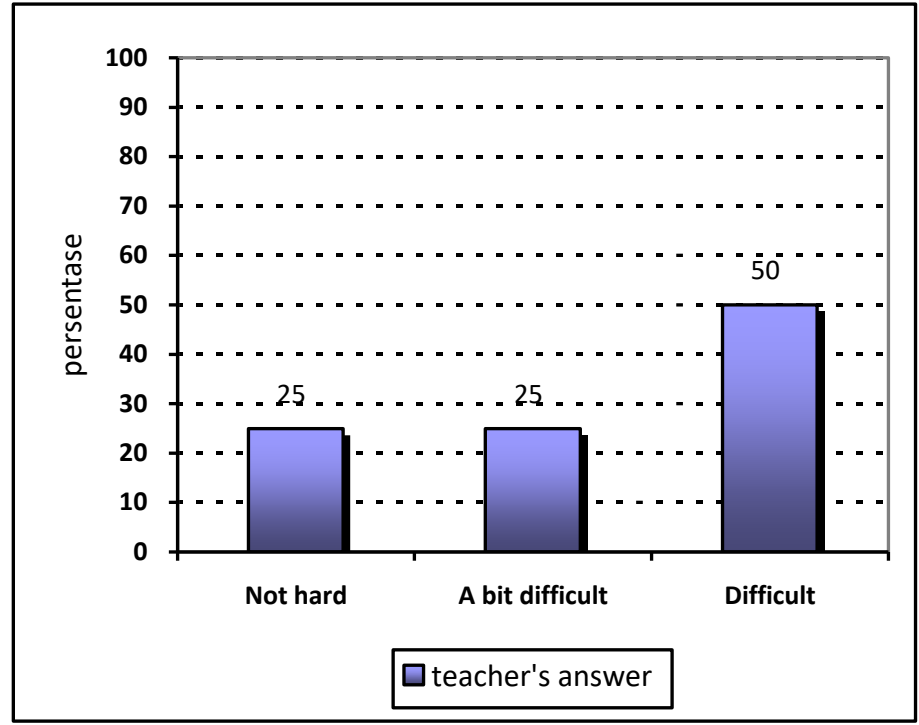

Figure 4. Teacher responses in the preparation and development of assessment based learning designs.

From figure 4 it can be seen, $50 \%$ of teachers have difficulty in preparing and developing assessment-based learning designs that are in accordance with process standards and want training in preparing and developing an Assessment for Learning (AfL). In order for the implementation and application of the Assessment for Learning (AfL) to be effective and efficient and in accordance with process standards, it is better if the teacher through the Subject Teacher Consultation (MGMP) in science subjects (chemistry, physics and Biology) conducts the preparation and development of the Assessment for Learning (AfL) in a comprehensive manner. independently adapted to the nature and character of the local wisdom of each region.

Aent for Learning (AfL) in addition to functioning for formative assessment, is also an assessment that aims to provide feedback to students so that their learning goals can be achieved effectively. The implementation of the Assessment for Learning (AfL) does not mean that the teacher is the main source of feedback, but places the teacher as a control system that facilitates student learning more effectively. Although many studies have been conducted, formative assessment has shortcomings and more research is needed, but the fact obtained from the research conducted to date is that almost all studies link formative assessment with meaningful student learning outcomes. The implications of the results of this study can contribute in the form of information about Assessment for Learning (AfL) in science learning, in the form of the need for teachers to further pursue student involvement in continuous assessment through the implementation of assessment-based learning, both assessments during the learning process (formative assessment) and assessments. self and colleagues. Recommendations for future researchers, researchers suggest further and more in-depth research related to the implementation of the assessment-based learning model implementation in science learning activities.

\section{REFERENCES}

Alt, D. (2018). Teachers' practices in science learning environments and their use of formative and summative assessment tasks. Learning Environments Research, 21(3), 387-406. https://doi.org/10.1007/s10984-018-9259-z 
Ansarin, A. A., \& Khatibi, S. P. (2018). The relationship between multiple intelligences and language learning strategies and gender. English Language Teaching, 11(5), 84-94. https://doi.org/10.5539/elt.v11n5p84

Azman, A. R., Muhammad, S. S., Nurkhamimi, Z., \& Hasanah, A. K. (2018). An evaluation of Global Zakat Game (GZG) as edutainment board game in enhancing Zakat education in Malaysia. Educational Research and Reviews, 13(5), 166-172. https://doi.org/10.5897/err2018.3487

Balan, A. (2010). Assessment for learning: A case study in mathematics education. In Faculty of Education and Society: Vol. Doctoral t, 84(1), 1-186.

Chueachot, S., Srisa-Ard, B., \& Srihamongkol, Y. (2013). The development of an assessment for learning model for elementary classroom. International Education Studies, 6(9), 119-124. https://doi.org/10.5539/ies.v6n9p119

Eriyanto, M. G., Roesminingsih, M. V, \& Soeherman, I. K. (2021). The effect of learning motivation on learning independence and learning outcomes of students in the package $\mathrm{c}$ equivalence program. IJORER: International Journal of Recent Educational Research, 2(4), 455467. https://doi.org/10.46245/ijorer.v2i4.122

Hanafy, M. S. (2014). Konsep dan pembelajaran. Lentera Pendidikan, 17(1), 66-79.

Heitink, M. C., Van der Kleij, F. M., Veldkamp, B. P., Schildkamp, K., \& Kippers, W. B. (2016). A systematic review of prerequisites for implementing assessment for learning in classroom $\begin{array}{llll}\text { practice. Educational } & \text { Research }\end{array}$ https://doi.org/10.1016/j.edurev.2015.12.002

Hignasari, L. V., \& Supriadi, M. (2020). Pengembangan e-learning dengan metode self assessment untuk meningkatkan hasil belajar matematika mahasiswa universitas Mahendradatta. Jurnal Kependidikan: Jurnal Hasil Penelitian dan Kajian Kepustakaan di Bidang Pendidikan, Pengajaran dan Pembelajaran, 6(2), 206-216. https://doi.org/10.33394/jk.v6i2.2476

Kippers, W. B., Wolterinck, C. H. D., Schildkamp, K., Poortman, C. L., \& Visscher, A. J. (2018). Teachers' views on the use of assessment for learning and data-based decision making in classroom practice. Teaching and Teacher Education, 75(1), 199-213. https://doi.org/10.1016/j.tate.2018.06.015

Kulprasit, W. (2021). Assessment for Learning (AfL): Its role in 12 writing contexts. The New English Teacher, 15(1), 1-13.

Kurniawan, D. (2016). Penggunaan assessment for learning (AfL) melalui peer assessment untuk meningkatkan mathematical problem solving. JP3M: Jurnal Penelitian Pendidikan dan Pengajaran Matematika, 2(2), 87-98. https://doi.org/10.37058/jp3m.v2i2.160

Lasry, N., Charles, E., \& Whittaker, C. (2014). When teacher-centered instructors are assigned to student-centered classrooms. Physical Review Special Topics - Physics Education Research, 10(1), 1-9. https:// doi.org/10.1103/PhysRevSTPER.10.010116

Lee, I., \& Coniam, D. (2013). Introducing assessment for learning for EFL writing in an assessment of learning examination-driven system in Hong Kong. Journal of Second Language Writing, 22(1), 34-50. https://doi.org/10.1016/j.jslw.2012.11.003

Leong, W. S., Ismail, H., Costa, J. S., \& Tan, H. B. (2018). Assessment for learning research in East Asian countries. Studies in Educational Evaluation, 59(3), 270-277. https://doi.org/10.1016/j.stueduc.2018.09.005

Mumpuni, K. E., \& Ramli, M. (2018). Penerimaan dan pengetahuan mahasiswa tentang assessment for learning students ' understanding and approvement toward assessment for learning. Jurnal Pendidikan Biologi, 11(1), 55-60. http://dx.doi.org/10.20961/bioedukasiuns.v11i1.19746

Nwani, K. (2021). Perception of teacher effectiveness and its role in optimising students' learning in five primary schools in Lagos State. Thesis. University of Leicester. https://doi.org/10.25392/leicester.data.14762181.v1

Purnomo, Y. W. (2015). Pengembangan desain pembelajaran berbasis penilaian dalam 
$\begin{array}{llll}\text { pembelajaran } \quad \text { matematika. Cakrawala Pendidikan, } & \text { 34(2), }\end{array}$ .https://doi.org/Universitas Negeri Yogyakarta

Spector, J. M., Ifenthaler, D., Sampson, D., \& Al., A. (2016). International forum of educational technology \& society technology enhanced formative assessment for 21st century learning linked references are available on jstor for this article: Technology enhanced formative assessment 21st century learning. Journal of Educational Technology E Society, 19(3), 58-71.

Sulhadi, S. R. A. R. (2017). Analisis pembelajaran fisika kelas X SMA negeri di kota Cirebon berdasarkan literasi sains. Physics Communication, 1(2), 12-18. https://doi.org/10.15294/physcomm.v1i2.10402

Tagg, B., \& Wang, S. (2016). Globalisation, commercialisation, and learning to play at KidZania Kuala Lumpur. International Journal of Play, 5(2), 141-158. https://doi.org/10.1080/21594937.2016.1203643

Triwiyono, E. (2017). Pengembangan assessment for learning (AfL) melalui lesson study pada praktik pemesinan SMK sesuai kurikulum 2013. Jurnal Dinamika Vokasional Teknik Mesin 2(60), 28-36. https://doi.org/10.21831/dinamika.v2i1.13497

Wijekoon, C. N., Amaratunge, H., De Silva, Y., Senanayake, S., Jayawardane, P., \& Senarath, U. (2017). Emotional intelligence and academic performance of medical undergraduates: A cross-sectional study in a selected university in Sri Lanka. BMC Medical Education, 17(1), 111. https:/ / doi.org/10.1186/s12909-017-1018-9

Winorno, Zuhri, M., Faculty, E., Sutomo, I., Widhyahrini, K., \& Program, P. (2019). Development of assessment for the learning of the humanistic model to improve evaluation elementary school mathematics. International Journal of Instruction, 12(4), 49-64.

Yusrizal, Y., Suliyanah, S., \& Basri, T. H. (2017). Analysis of knowledge, understanding and skills of physics teachers of state senior high schools in developing and analyzing test items. Jurnal Pendidikan IPA Indonesia, 6(2), 245-251. https://doi.org/10.15294/jpii.v6i2.10679

Yusron, E., \& Sudiyatno, S. (2021). How is the impact of assessment for learning ( AfL ) on mathematics learning in elementary schools?. Jurnal Prima Edukasia, 9(1), 75-84. https://doi.org/10.21831/jpe.v9i1.34865

\author{
Tatang Mulyana (Corresponding Author) \\ Pakuan University \\ Postgraduate Program, Science Education Study Program \\ Jl. Pakuan, RT.02/RW.06, Tegallega, Central Bogor District, Bogor City, West Java 16129, Indonesia \\ Email: tatang.072619014@unpak.ac.id \\ Dr. Surti Kurniasih, M.Si \\ Pakuan University \\ Postgraduate Program, Science Education Study Program \\ Jl. Pakuan, RT.02/RW.06, Tegallega, Central Bogor District, Bogor City, West Java 16129, Indonesia \\ Email: surti_kurniasih@unpak.ac.id
}

\title{
Dr. Didit Ardianto, M.Pd.
}

Pakuan University

Postgraduate Program, Science Education Study Program

Jl. Pakuan, RT.02/RW.06, Tegallega, Central Bogor District, Bogor City, West Java 16129, Indonesia Email : diditardianto@unpak.ac.id 